\title{
From Nuoro to Nobel: the impact of multiple mediatorship on Grazia Deledda's movement within the literary semi-periphery
}

\section{Cecilia Schwartz}

To cite this article: Cecilia Schwartz (2018): From Nuoro to Nobel: the impact of multiple mediatorship on Grazia Deledda's movement within the literary semi-periphery, Perspectives, DOI: 10.1080/0907676X.2018.1439979

To link to this article: https://doi.org/10.1080/0907676X.2018.1439979

Published online: 26 Feb 2018.

Submit your article to this journal $\sqsubset$

Q View related articles ¿

View Crossmark data $\complement$ 


\title{
From Nuoro to Nobel: the impact of multiple mediatorship on Grazia Deledda's movement within the literary semi-periphery
}

\author{
Cecilia Schwartz \\ Department of Romance Studies and Classics, Stockholm University, Stockholm, Sweden
}

\begin{abstract}
This study aims to highlight the impact of multiple mediatorship on transnational circulation by focusing on the Italian Nobel Laureate Grazia Deledda. Drawing on two previous studies, I argue that a combination of field theory and social network analysis is a fruitful way of understanding how multiple mediatorship is performed in the semi-peripheral areas of world literature. The analysis shows that Deledda's success in Sweden depended neither on the translation of her work into central languages (English, French, German) nor on the support of single influential mediators in the target culture, but rather on the efforts of three interconnected networks of cultural mediators linking Sweden and Italy. These networks are identified, described and analyzed in order to obtain a better understanding of the features that are crucial to creating successful connections in the literary semi-periphery.
\end{abstract}

\section{ARTICLE HISTORY}

Received 27 June 2017

Accepted 1 February 2018

\section{KEYWORDS}

social network analysis; multiple mediatorship; semiperiphery; Swedish; Italian; Deledda; transnational literature

\section{Introduction}

How does literature cross national, cultural and linguistic borders? The scholarly answers to this topical research question usually draw from two opposing methodological perspectives: either a micro-perspective is adopted, emphasizing the efforts of single mediators, or the query is addressed from a macro-perspective, following theoretical models of how literature circulates in the world-system of translations. Both micro- and macro-level approaches certainly provide useful insights into literary dissemination throughout the world, and yet they ignore some crucial aspects related to what I call multiple mediatorship, which is used in order to highlight the great number of individuals who are involved, more or less directly, in transnational literary circulation. As for the case studies of cultural mediators, these usually focus on single actors and their national literary contexts, but rarely on their 'transnational relations and their participation in multiple cultural fields' (Meylaerts, Gonne, Lobbes, \& Sanz Roig, 2017, p. 68). The world-system approach, on the other hand, tends to focus on the larger movements in the international field, which often means literature circulating from the center to the periphery, while exchanges between the peripheries are ignored. Franco Moretti, for instance, has stated that 'movement from one periphery to another (without passing through the center) is almost unheard of (2003, p. 75). According to Casanova (2004), literary circulation depends 
largely on the position of the source language in the international republic of letters, and Heilbron stated that peripheral language areas import literary works from each other only after they have been translated into a central vehicular language, i.e. German, French and English (Heilbron, 1999, p. 435). When it comes to the relationship between semi-peripheral languages, such as Italian and Swedish, the world-system model does not offer any useful insights. According to Heilbron, the semi-peripheral languages form an evasive category, consisting of 'approximately six languages' that 'cannot be separated very clearly from the peripheral ones' (Heilbron, 1999, p. 434). A more recent article (van Es \& Heilbron, 2015) does not provide any further clarifications about the semi-peripheral condition. Recently, however, there has been some scholarly interest with regard to this neglected area of world literature (Pięta, 2016; Schwartz, 2017).

In this study I will focus on an author's trajectory within the literary semi-periphery, namely how the works of the Italian writer Grazia Deledda (1871-1936) reached Sweden. I will show that her success in Sweden can be explained neither from a worldsystem perspective nor by focusing on single mediators. Instead, I argue that the spread of her name and work occurred as a result of multiple mediatorship, i.e. the combined contributions of several mediators as members of interconnected networks. The concept is a modification of the notion of multiple translatorship, coined by Jansen and Wegener (2013). Multiple translatorship is closely related to the issue of transnational literary mediation, as it stresses 'the collaborative nature of translation' and 'emphasize[s] how agents interact, negotiate and struggle for influence in the various phases leading up to the translated text' (2013, p. 5). However, the term also embodies other aspects related to the translation product, as well as 'authority', which makes it too broad for the purposes of this study. Moreover, the term multiple translatorship addresses literary translation rather than literary mediation. Even though translation is an important component of literary circulation, it is not always central to mediation. To illustrate the situation concerning Deledda's path to international consecration, I suggest that a combination of social network analysis and field theory can be used in order to make multiple mediatorship visible and offer a more nuanced picture of circulation in the semi-periphery.

Why is Grazia Deledda's case so intriguing? For a start, although her name is today almost forgotten, Deledda was once considered a European literary star, as she was the second woman, after the Swedish writer Selma Lagerlöf, to receive the Nobel Prize in Literature - a consecration that formally permitted her to enter the inner circle of world literature. However, the Nobel Prize to Deledda is generally considered to be one of the most flagrant mistakes of the Swedish Academy. On the very few occasions in which Deledda's name is remembered nowadays, it is either mentioned as one of the failures of the Swedish Academy $^{1}$ or as an example of forgotten Nobel Laureates. Since the turn of the millennium, however, her work has garnered some vindication, not least among Italianists outside Italy (Heyer-Caput, 2008; King, 2005). From a Swedish perspective, Deledda is, after Alberto Moravia, the most translated Italian author of the twentieth century.

Even though she became successful inside and outside the Italian borders in the first decade of the last century, Deledda faced several obstacles on her way to literary recognition. In many ways, she was born into the worst conditions for an author in spe: a female with only a few years of schooling, who was brought up in the small town of Nuoro in the Sardinian hinterland, which belonged not only to the European margins at the time but also to the utmost periphery of Italy. Deledda's background and conditions 
were not ideal, nor were her works conceived of as particularly groundbreaking or innovative: her narratives - mostly folkloristic, romantic family dramas set in an almost archaic Sardinia - could be placed in the borderland of verismo (i.e. the Italian form of naturalism) and symbolism, despite evolving over the years into a psychological style of writing that was more in line with the modernistic tendencies prevailing at the beginning of the last century (cf. Heyer-Caput, 2008). Deledda debuted as a writer in 1888, and 11 years later the first translation of her work appeared. ${ }^{2}$ In the first decade of the 1900s she had an international breakthrough, starting simultaneously in Sweden and France, and from 1913 she was nominated 12 times as a candidate for the Nobel Prize in Literature, which she received in $1926 .^{3}$

So how did her work and name reach Sweden? Was it due to many translations into central languages - as suggested by the world-system theory - or did she have a particularly powerful and influential translator, critic or publishing house in Sweden? In the following, I will focus on the Swedish translations of Deleddian works published before the Nobel Prize in order to find out whether her works were supported by any single literary mediator, and to what extent this was dependent on translations into central languages (French, German, English).

As shown in Table 1, up to 1926 five of Deledda's works had been translated into Swedish by four different translators and were published by four different companies. Of these works, very few got any reviews at all in the Swedish press. Only Murgrönan (The ivy), published in 1926 by the largest and most influential publishing house, Bonniers, received some attention on the cultural pages. These figures indicate that Deledda lacked the support of a single literary mediator.

Furthermore, the rate and rhythm of the Swedish translations conform to those in the more central language areas:

Figure 1 demonstrates that in 1899 one translation was made into French; in 1903, there was one more in French and one in Swedish; in 1905, two translations appeared in English and one in French, and so on. However, as shown below, the selection of titles in Sweden (appearing in 1903, 1907, 1909, 1922 and 1926) was quite independent from the titles chosen in the central languages (Table 2):

Only in the case of the novel Nostalgie, published in 1922, did the Swedish translation come after the ones in the central languages, but the temporal distance separating it from the other translations - English in 1905, French in 1909 and German in 1912 - suggests that the decision to do so depended on other circumstances. In one other case, Il vecchio della montagna, a translation from a central language (German) precedes the Swedish version, but the probability that the Swedish translation was motivated by the translation into German is very small. Why? The Swedish translator of this specific title was Anton

Table 1. Swedish translations of Deleddian works before the Nobel prize.

\begin{tabular}{lccc}
\hline Swedish title $^{\mathrm{a}}$ & Year & Publishing house & Translator \\
\hline Elias Portolu & 1903 & Wahlström \& Widstrand & Ebba Atterbom \\
På onda vägar & 1907 & Ljus & Anton Lindsström \\
Herdar & 1909 & Ljus & Anton Lindsström \\
Regina Tagliamari/Nostalgi & 1922 & Hökerbergs/Schildts & Erik Kihlman \\
Murgrönan & 1926 & Bonniers & Ernst Lundquist \\
\hline
\end{tabular}

${ }^{a}$ The Italian titles are: Elias Portolu, La via del male, II vecchio della montagna, Nostalgie, L'edera. 


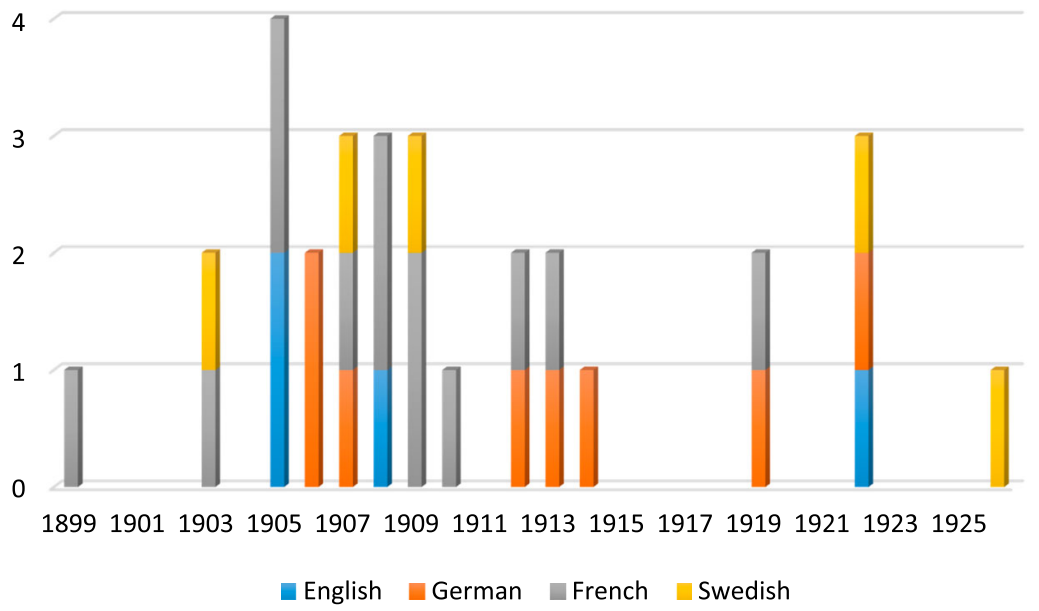

Figure 1. Deledda in English, German, French and Swedish 1899-1926.

Lindsström, who had already translated another Deleddian title in 1907. Lindsström was an expert on Italian literature and, as we shall see later, one of the most prolific mediators of Deledda's work in Sweden. I therefore assume that the choice to translate Il vecchio della montagna did not depend on the existence of a German version.

Altogether, the case of Deledda does not confirm the idea of central languages as transitional languages. This conclusion instead suggests that Deledda's novels were imported into Sweden directly from Italy. Another indication of the existence of such direct contacts is that all 12 nominations for the Nobel Prize came from either Sweden or Italy. ${ }^{4}$

Taken together, the Italian-Swedish Nobel nominations of Grazia Deledda, the absence of a powerful promoter in the field of publishing, translation and reception, as well as the independent selection of titles suggest that Deledda's works reached Sweden via paths that cannot be explained either by influences from more central literatures or by interventions of a single mediator. Rather, I suggest that her name and work were spread to Sweden through multiple mediatorship, many individuals included in interconnected networks.

With respect to the aforementioned approaches - case studies of single mediators and world-system perspectives - the network analysis offers a less hierarchic and non-linear way of describing the conditions for transnational circulation. Instead of presenting it as a formalized process following a specific order, the network perspective illustrates

Table 2. Years of the first Italian, Swedish, German, French and English titles of the first five Deleddian works translated into Swedish.

\begin{tabular}{|c|c|c|c|c|c|}
\hline Title & Italian & Swedish & German & French & English \\
\hline Elias Portolu & $1903^{a}$ & 1903 & 1906 & 1903 & 1992 \\
\hline La via del male & $1906^{\mathrm{b}}$ & 1907 & & 1908 & \\
\hline Il vecchio della montagna & 1900 & 1909 & 1906 & & \\
\hline Nostalgie & 1905 & 1922 & 1912 & 1909 & 1905 \\
\hline L'edera & 1906 & 1926 & & 1998 & \\
\hline
\end{tabular}

The year that is indicated concerns its publication in a volume. It had previously appeared as a serial in Nuova Antologia in 1900.

${ }^{\mathrm{b}}$ The novel was first published in 1896, but it underwent thorough revisions by the writer herself in 1906 and 1916. The Swedish translation is based on the revised version from 1906. 
the complexity and disorder, not to mention chaos, of literary mediation (Tahir-Gürçaglar, 2007). The advantage is that the network perspective gives a more adequate picture of all the institutions and individuals that are actually involved in the complex process of literary mediation. Furthermore, it stresses multiple mediatorship, which has not been taken into consideration to the extent that it should be. Case studies of transnational circulation often underscore the impact of important individuals and, by doing so, conform to traditional literary studies. In this article, it is argued that with regard to foreign literature from a semi-peripheral area, there are a large number of individuals involved - not only those participating in the very process of producing or receiving a given work, but also actors contributing more implicitly by spreading the name of the writer of that work in a foreign culture. For this purpose, adopting a network perspective is inevitable, and I argue that Social Network Analysis (SNA) is preferred to Bruno Latour's actor network theory (ANT), since it allows for the use of historical sources and archive material to reconstruct former networks. According to Hélène Buzelin, ANT is not very useful for reconstructing historical processes; rather, it is necessary for networks to be explored in real time (2007, p. 54). ${ }^{5}$

More specifically, the network perspective that is adopted in this study draws on the work of two scholars who have argued for a combination of field theory and SNA in addressing literary circulation: Gisèle Sapiro (2006), who launched the hypothesis that field theory and SNA can be a fruitful combination if the latter is used as a method for examining the literary field; and Anthony Pym (2007), who conducted a study of French-German translator networks that existed at the end of the 1800s. Pym's results show that the literary relations between France and Germany occurred at an intercultural level, thanks to a network between the two cultures and by individuals whose major task was to define the relations between the French and German cultures.

Drawing on Sapiro and Pym, I will undertake a reconstruction of the networks linking Deledda to the Swedish cultural field and highlight several cultural mediators and their relations to each other, as well as to the Italian writer, in order to shed light on the collective preparatory efforts during the first two decades of the 1900s that would lead to the Nobel Prize going to Grazia Deledda. Previous studies of the internal discussions among the members of the Swedish Academy that led to the formal decision to award the work of Deledda show that this decision was not unanimous (Svensén, 2001, pp. 103-105). ${ }^{6}$

Methodologically, I follow a five-step analysis:

(1) a reconstruction of Deledda's own network, her egocentric network, based on previous biographical research. ${ }^{7}$ An egocentric network is defined as the 'network surrounding one node' (Marin \& Wellman, 2014, p. 13). Node is a basic concept in SNA referring to each member or unit of a network.

(2) within Deledda's egocentric network, those individuals or nodes that were interconnected with the Swedish field are identified. This is done in order to find out whether an intercultural field existed between distant and semi-peripheral areas, such as Sweden and Italy, similar to the one Pym (2007) revealed between central and neighboring Germany and France.

(3) I examine whether the identified nodes were part of any common whole networks. Whole networks are the opposite of ego networks as they 'take a bird's eye view of 
social structure, focusing on all nodes rather than privileging the network surrounding one particular node' (Marin \& Wellman, 2014, p. 13).

(4) I analyze the structure of these networks according to Sapiro's (2006) model, in order to determine their importance in the spreading of Deledda's work outside the traditional channels (publishing houses, book reviews, etc.).

(5) I focus on the nodes and their position in the network and in the cultural field. The latter positions are analyzed following Casanova (2010).

\section{Three intercultural networks}

Quite contrary to the image of Deledda as a Sardinian peasant woman who did not take part in the mundane artistic life in Rome (an image promoted not least by herself), the reconstruction of her egocentric network reveals extensive national and international contacts. Very few of the international nodes, however, can be directly linked to Sweden, which again indicates that the connections should be understood as a separate intercultural field between Sweden and Italy. In this field, the identification of the 'Swedish' nodes in Deledda's egocentric network suggests that they belonged to three intercultural spheres, or networks, which were all quite different from each other:

- The Swedish Academy (Svenska Akademien, SA): During the examined period (1900-1925), there were many Italophiles in the SA, and some of them were in contact with Deledda: Carl Bildt, Anders Österling, Selma Lagerlöf, Henrik Schück, Oscar Montelius, Erik Axel Karlfeldt and Verner von Heidenstam. ${ }^{8}$

- The Swedish-Italian Society (Svensk-italienska sällskapet, SIS): ${ }^{9}$ A society founded in Stockholm, 9 February 1910, on the initiative of the Italian Nobel Peace Prize Laureate Ernesto Teodoro Moneta (1833-1918), who had visited Stockholm in 1909. By that same time, a sister society had been founded in Rome. One of the prestigious members of this Roman society was Angelo De Gubernatis, Deledda's foremost mentor and protector since the earliest years of her career (cf. Dolfi, 1979; Heyer-Caput, 2008).

- Intellectual women in Rome (IWR): Even though this was not a formal network, there are several proofs of its existence. The first decades of the 1900s formed a period during which Swedish female writers, artists and journalists started traveling to the Eternal City, with some even settling down there for longer periods. These women have not yet been studied as a group or network, but several case studies, as well as biographical and autobiographical works, are available that depict life in Italy (mainly in Rome). ${ }^{10}$

In the following, I will analyze these three networks following Sapiro's model (2006), which takes into consideration the network's (1) structure and size; (2) degree of institutionalization (formal, semi-formal or informal); (3) degree of openness (closed, half open or open); (4) objectives and (5) relationships to other networks. The importance of the network's relationships should not be underestimated, since networks without connections to other networks have limited power to influence. These connections are performed by nodes that are interconnected to other networks, or so-called bridges (Marin \& Wellman, 2014, p. 6). In her model, Sapiro also included two more aspects of the network, namely the members' objective characteristics (age, sex, position, etc.) and 
Table 3. Features of intercultural networks.

\begin{tabular}{lccccc}
\hline Network & Size & Formality & Openness & Literary objectives & Connectedness \\
\hline The Swedish Academy (SA) & Small & Formal & Closed & Consecration & SIS, IWR \\
The Swedish-Italian Society (SIS) & Medium & Semi-formal & Half open & Promotion & SA, IWR \\
Intellectual women (IW) & Large & Informal & Open & Support & SA, SIS \\
\hline
\end{tabular}

social capital. Since these two issues concern the members of the network, I will treat them separately when I take into consideration the nodes (Table 3).

In the years in which Deledda's name recurred as a candidate for the Nobel Prize (1913-1926), the Swedish Academy comprised a total of 25 individuals. ${ }^{11}$ The network was - and still is - highly formal and closed: only individuals who have been elected are allowed to enter the Swedish Academy. All relationships are binary - i.e. the nodes all have contact with each other through regular meetings (every Thursday). Within the network, the Nobel Committee should be regarded as a clique, 'in which every node is tied directly to every other node' (Marin \& Wellman, 2014, p. 16). Surrounding the network, there are also a few satellites, such as the literary experts responsible for monitoring their specific language area.

The SA has many different objectives, but the one that is of primary interest to this study regards the mission to elect a Nobel Laureate. In more general terms, the Academy's purpose is therefore to consecrate authors from different parts of the world. The high prestige of this network positions it in the very center of Swedish cultural life.

The SIS was definitely larger than the SA, even though it has not been possible to determine the exact number of members. The network could be described as half open, and semi-institutional, in the sense that it had its own statutes and required from its members a close relation to Italy (see below). The network's explicit objective was 'to promote literary, artistic, scientific and commercial relations with Italy' (Dagens Nyheter 10 February 1910).

As already mentioned, the network of female intellectuals who were active in the intercultural field between Italy and Sweden was not institutionalized. However, a study that does not adopt a network perspective will not be able to discern the efforts of multiple mediatorship in the shadow. According to Sapiro, the network analysis 'permits to identify the multipositionality and sometimes occult intermediary role of certain individuals' (2006, p. 56, my tr.). ${ }^{12}$ These female intellectuals constituted a large, open and informal network with several cliques within the larger group. The relations among the nodes were generally based on friendship, and their main objectives could be described in terms of interconnecting intellectual women, supporting female artists and writers, as well as engaging in women's suffrage.

\section{The nodes}

In the following, I analyze the nodes of the networks. First, a general description of their common characteristics (sex, age, position) is given, and I then focus on some of the nodes. In terms of position, the analysis is based on Casanova's (2010) identification of three types of mediators operating in the literary field: the ordinary mediator, the charismatic mediator and the institutional mediator. According to Casanova, the position of the intermediaries in the literary field is of great importance with respect to consecrating foreign 
Table 4. Characteristics of the nodes.

\begin{tabular}{|c|c|c|c|c|}
\hline Network & Sex & Age & Social position & Field \\
\hline SA & Male & Average: 66 years & $\begin{array}{l}\text { Institutional } \\
\text { Charismatic }\end{array}$ & $\begin{array}{l}\text { Literature } \\
\text { Language } \\
\text { Art } \\
\text { History } \\
\text { Law }\end{array}$ \\
\hline SIS & Male and female & Adult (mixed ages) & $\begin{array}{l}\text { Institutional } \\
\text { Ordinary }\end{array}$ & $\begin{array}{l}\text { Literature } \\
\text { Art } \\
\text { Mathematics } \\
\text { Medicine } \\
\text { Military } \\
\text { Diplomacy } \\
\text { Language }\end{array}$ \\
\hline IWR & Female & Adult (mixed ages) & $\begin{array}{l}\text { Institutional } \\
\text { Charismatic } \\
\text { Ordinary }\end{array}$ & $\begin{array}{l}\text { Literature } \\
\text { Art } \\
\text { Journalism }\end{array}$ \\
\hline
\end{tabular}

works (2010, pp. 299-302). Ordinary mediators are basically invisible in the literary field: they are translators or experts in a certain literature who provide other agents with information about literary news, but they lack the power to consecrate works of fiction themselves. Charismatic mediators are writers, translators or other respected cultural figures whose names are so famous that these are enough to consecrate a foreign author. Institutional mediators are those who are able to consecrate in the name of an institution such as a university or an academy with high prestige (Table 4).

\section{The Swedish Academy}

To begin, the average age of the nodes constituting the Swedish Academy was 66 years, and, except for Selma Lagerlöf, they were all men. Their positions in the cultural field were strong before becoming part of this prestigious network (otherwise they would not have been elected) and did not weaken after obtaining a lifelong seat in the Academy. Although not all of them possessed literary capital, they all possessed a great amount of symbolic capital in their particular field of activity, which, in addition to the literary field, included linguistics, history of arts, history and jurisprudence. Moreover, their positions could be characterized as both institutional and charismatic.

Among these members, at least seven had a very strong relation to Italy and/or Italian culture. I will consider these contacts briefly in chronological order, following the year of their election into the Academy. Carl Bildt was a diplomat in Rome in the years 1889-1902 and 1905-20, where he enjoyed 'a position and a reputation as probably few foreigners were granted' (cf. Jacobson). This charismatic mediator, with more or less intimate relations with influential Italian and international politicians, was a great admirer of Grazia Deledda's work, and he nominated her for the Nobel Prize no fewer than eight times (Svensén, 2001, p. 103).

Another Italophile in the network was the poet and author Erik Axel Karlfeldt, who held the position of permanent secretary of the SA in the years 1913-1931 - i.e. the years in which Deledda was nominated and finally received the Nobel Prize. In what has been deduced from the correspondence between Karlfeldt and Bildt, the former was 'courteous, respectful, but not unreservedly enthusiastic' towards Bildt's recurrent proposals of giving the Prize to Deledda (Björkman, 1998, p. 137, my tr.). 
A professor of literary history at Uppsala University, Henrik Schück was, together with Bildt, the Academy member that most insistently propagated for a prize to Deledda, and he also nominated her twice as a candidate (Svensén, 2001, p. 103). Another important node of the SA was Anders Österling, who would later become one of the foremost translators, introducers and critics of Italian literature in Sweden (Schwartz, 2016, pp. 77-78). Even though he was at first quite opposed to the idea of awarding Deledda, he would soon become one of her supporters, writing the prefaces to her novels Murgrönan (L'edera) and De levandes Gud (Il dio dei viventi), and publishing them in the book series Gula serien, which he edited for Sweden's most prestigious publishing house, Bonniers.

While the individuals mentioned above advocated explicitly for Deledda's authorship, or in some way contributed to her consecration, there were at least two other members whose explicit roles remain to be attested to, but who are, all the same, interesting in their roles as bridges to the other networks. The archeologist and cultural historian Oscar Montelius (1843-1921), who was elected into the Swedish Academy in 1917, had not only published several studies about Italy, but had also been chair of the SIS in Stockholm (see below). He was, at least, loosely connected to the female network as well, thanks to his travels to Rome with his wife, Agda Montelius, who was the chair of the feminist association Fredrika Bremer-förbundet from 1903-20. Another member who performed such a bridge function to one of the other networks was the author and former Nobel Laureate Selma Lagerlöf (elected in 1914), ${ }^{13}$ who also belonged to the network of female intellectuals due to her travels to Italy. Moreover, Lagerlöf had been in contact with Deledda, which is confirmed by the correspondence between the two writers. In one letter to Deledda, Lagerlöf described herself as an admirer of Deledda's works (Dolfi, 1987, p. 71).

Finally, one more node ought to be mentioned: Karl August Hagberg. Even though he was only a member of the Nobel Institute (and not of the SA), Hagberg's importance to Italian literature cannot be ignored. He became a member of the Nobel Institute in 1908, where he represented the belles-lettres of the South Romance languages, mainly Italian. One of his tasks was to compose summaries and reports about the nominated Italian candidates for the Nobel Committee of the SA. Hagberg not only wrote several reports on Deledda for the Nobel Committee, but he would later become one of her translators. In April 1917, Hagberg contacted the Italian author Dino Provenzal for information on contemporary Italian writers. Due to the difficulty in gaining access to magazines during the war, he asked Provenzal to update him on contemporary literary trends in Italy, and in particular wanted to know whether Deledda (whom he greatly esteemed) had written something recently, or if any important critiques of her works had been published in Italy. In the letter, Hagberg underscored that he wanted to see an Italian Nobel Laureate in literature soon. Provenzal, who did not know Deledda personally, wrote to her to request the desired information for Hagberg. Deledda then answered Hagberg herself, which she regretted doing afterwards since she felt as if it appeared that she had been begging for the prize (King, 2005, pp. 161-162).

\section{The Swedish-Italian Society}

The common denominator of the nodes of the SIS in Stockholm was their relation to Italy, which was defined as follows: 'members of the Italian colony here or Swedes that in one 
way or another have connections to Italy and Italians' (Dagens Nyheter 10 February, my tr.). ${ }^{14}$ Otherwise, this network is the most heterogeneous of the three, mixing men and women, young and old, Italians and Swedes. As in the case of the members of the SA, the nodes held positions in different fields: diplomacy, academies, universities, military, tourism and medicine. What distinguishes them, however, is that they all enjoyed very high positions in society. Some of the network's foremost nodes had a strong academic character - university professors and Ph.D. ${ }^{15}$ - and a remarkable number belonged to the Swedish or Italian aristocracy. ${ }^{16}$

Even though it is apparently not possible to obtain a complete list of the members, four articles about the Society's meetings were published in the newspaper Dagens Nyheter. ${ }^{17}$ Among the members mentioned in these articles, we can note several bridges to the other networks. There were at least four bridges to the SA. One was Professor Karl Warburg, who was the SA's expert on German and Scandinavian literature, and who had also founded, in 1900, the same Academy's library (Svenska Akademiens Nobelbibliotek), which was the first international library in Scandinavia. Warburg was also one of the leading critics at the time and was regarded as being rather open-minded, not least towards female writers. Together with the academician Henrik Schück (see above), he had compiled an Illustrated Literary History (Illustrerad svensk litteraturhistoria 18961897). Other bridges to the SA included the previously mentioned Olof Montelius, as well as the siblings Holger Nyblom and Ellen Lundberg-Nyblom, the son and daughter, respectively, of the former member of the SA Carl Rupert Nyblom. The Nyblom siblings were also bridges to the female network, not least of all Ellen, who had lived in Italy for many years (see below). Other important members of the SIS were Gösta MittagLeffler, a professor of mathematics and a radical advocate for women's emancipation, ${ }^{18}$ and Helmer Key, who became the chair of the SIS in 1911 (Dagens Nyheter 6 May 1911). Key was a professor of literary history, having written a doctoral thesis on Alessandro Manzoni's masterpiece, The Betrothed, and was the editor-in-chief of the prestigious newspaper Svenska Dagbladet. Although somewhat distant, his family ties to Ellen Key (see below) possibly made him a bridge to the female network.

What can be concluded from the intricate relations described above? First, the nodes were interconnected by different kinds of family ties. Second, the relation to Italy among the nodes holding institutional positions, and consequently with a considerable impact on Swedish cultural life, was extremely warm and intense. Third, the nodes of the SIS happened to gather persons with several contacts to the SA and to the female network. But did the network promote Deledda's works in a more direct way? Definitely. To illustrate how the SIS intervened in favor of Deledda, I will focus on two nodes: Anton Lindsström and Ellen Lundberg-Nyblom.

During the meetings with the SIS, one of the members would give a talk on a theme that related to Italy. These talks were usually about ancient Rome, but before a meeting in November 1910, Dagens Nyheter announced that Doctor Anton Lindsström would be giving a speech about Grazia Deledda's works (Dagens Nyheter, 23 November 1910). Even though Lindsström was a consecrator positioned between the ordinary and the institutional mediator, he seemed to have had a crucial position in the network, not least since he was elected vice president of the society in 1911. The network offered him a platform to speak about Deledda long before she was nominated as a candidate for the Nobel Prize in literature. The task was appropriate for Lindsström, who had translated two of Deledda's 
novels into Swedish (cf. Table 1), as both had been published as part of the Ljus' house cutprice book series (Ljus enkronasserie). Even though the first title had appeared in the same advertisement as August Strindberg's Svenska öden och äventyr (Dagens Nyheter 7 April 1907), it received very few reviews in the Swedish daily mail. The second title, Herdar, met the same fate, receiving only a brief and negative review in Dagens Nyheter. Not only did the inattentive and unsigned review confuse Sardinia and Sicily, but it also accused the translation of being 'careless and un-Swedish' (Dagens Nyheter 15 December 1909). This was a rather unfair critique that would much later be dismissed by Per Erik Wahlund, who argued that 'among the translators who have more or less rigidly interpreted [Deledda] into Swedish, the nimble Anton Lindsström stands in a class of his own' (1979, p. 140, my tr.). After this 'failure', however, Lindsström did not translate any other of Deledda's works. That he did not abandon his interest in it, however, is confirmed by the speech he gave at the Swedish-Italian autumn meeting in 1910, and by a study of Deledda's work published in the magazine Nordisk tidskrift (1912).

The other important node with relations to the SA, as well as to the female network in Italy, was the poet, artist and translator Ellen Lundberg-Nyblom. Her social capital was abundant: not only was she the daughter of Carl Rupert Nyblom, member of the SA, and the famous author Helena Nyblom, who both knew Italian, she was also married to the renowned professor and sculptor Theodor Lundberg. In the married couple's circle of friends there were several notables, such as Henrik Schück, Ellen Key, Axel Munthe and the Swedish Prince Eugen. Furthermore, Lundberg-Nyblom was a talented translator of Italian, having translated bestselling Italian works such as Matilde Serao's Il Paese della Cuccagna in 1892 and Edmondo De Amicis' Cuore in 1888. She lived in Italy both as a young girl and as an adult, which makes her a bridge to, as well as another node of, the female network.

By the time the SIS was founded, a sister compound had been established in Rome, in January 1910. During one of the first meetings in Stockholm, Baron Lage Staël von Holstein presented this Italian counterpart. From what I have been able to deduce, the chair of the Italian-Swedish Society in Rome was the professor of mathematics Vito Volterra. ${ }^{19}$ Among the members of this society, which was explicitly linked to the one in Stockholm, some individuals on the board were directly interconnected with Deledda; for instance, Angelo De Gubernatis and Matilde Serao (Dagens Nyheter 27 December 1910).

It has not been possible to determine for how long the SIS in Stockholm persisted, but traces in the press had already ceased by May 1911. However, in the spring of 1928 a similar society was founded, this time with Deledda supporters such as Henrik Schück and Anders Österling among its members. ${ }^{20}$

\section{Intellectual women in Rome}

If the former network was a rather heterogeneous one, the female network, in spite of its grandeur and open-ended margins, gathered nodes sharing quite similar characteristics: professional and intellectual women, working in Italy as writers, journalists, critics and translators. $^{21}$ There is, however, a difference between the symbolic capital of these women and their positions in the literary field: some of them, such as Ellen Key and Selma Lagerlöf, were internationally celebrated and are therefore to be regarded as charismatic consecrators, while others were more anonymous, such as the foreign correspondents Hilda Sachs and Gunhild Bergh. ${ }^{22}$ What many of them had in common, 
however, and what distinguishes them from the nodes in the other two networks, was that they knew Grazia Deledda personally, or at least they were interconnected with her for professional reasons. Two of the nodes in this large network, the charismatic Ellen Key and the ordinary mediator Ebba Atterbom, illustrate the huge differences in terms of symbolic capital and position in the literary field that distinguishes the nodes of this network from the other two.

Ellen Key (1849-1926) was a Swedish thinker and writer who was acquainted with the European cultural elite at the turn of the twentieth century. Among her friends were international names such as Rainer Maria Rilke, Martin Buber and Prince Eugen. As an advocate of women's rights, Key founded the women's association Tolfterna and the journal Nya Idun. However, she is best known for her book on education, The Century of the Child, which was translated into several languages, including English in 1909 and Italian in 1907; the ideas expressed in the work would later inspire such pedagogists as Maria Montessori. In the years 1906-1907, Key stayed in Rome where she came into contact with Sibilla Aleramo and Grazia Deledda. Her acquaintance with Deledda is highlighted in Henrik Schück's presentation of the Nobel Laureate in literature in 1926. In this speech, he recalled that it had been when Key appealed to Deledda to take an interest in the Prize for the sake of women that the Italian writer uttered the celebrated words: 'I belong to the past'. Both Ellen Key and Grazia Deledda were honorary members of the Austrian women's association Verein der Schriftstellerinnen und Künstlerinnen in Wien, founded in 1885 , 'to give support to the professional activity of female artists in a period in which the set places for the circulation of culture (...) were strictly male preserves' (Camboni, 2004, p. 30). There is no doubt that Ellen Key was one of the charismatic consecrators in Deledda's egocentric network.

Quite different is the case of Ebba Atterbom, who was Deledda's first Swedish translator. Atterbom lived in Italy in the 1890s and was a close friend of Selma Lagerlöf s friend and love Sophie Elkan. Atterbom was therefore drawn into Lagerlöfs circle of friends (cf. Furuland), and she began translating from Swedish into Italian around 1900, starting with some fairy tales by Helena Nyblom and a volume of Sophie Elkan's short stories entitled Novelle svedesi (1900). Her first translation from Italian into Swedish was Deledda's Elias Portolu, which was published in the autumn of 1903, the same year that the work was published in volumes in Italy and France (cf. Table 2). Except for her prestigious family name - she was the granddaughter of the famous Romantic poet Per Daniel Amadeus Atterbom - Ebba Atterbom did not have access to much symbolic capital. For instance, she did not offer the translation of Elias Portolu to the publishing house Wahlström \& Widstrand herself, but operated through an intermediary, Nanna Bendixsen, who was better acquainted with one of the publishers. ${ }^{23}$ Only after the publisher had accepted the offer did Atterbom contact them directly. The correspondence shows that she was in immediate contact with Deledda and that she had proposed the translation without knowing that it was about to be translated into French:

As late as today I received a card from her with the announcement that 'Elias Portolu' in Revue des Deux Mondes has had great success in France and that the publisher CalmanLevy now plans to publish it in book form. (Letter, 7 June 1903, my tr.) ${ }^{24}$

The reception of the novel utterly underscores that the Swedish literary field was not following its French counterpart: Elias Portolu hardly received any reviews at all in the 
Swedish press. When the novel was mentioned in Dagens Nyheter, it was simply described as 'Grazia Deledda's peculiar book Elias Portolu' (21 October 1903, my tr.). The failure of the first Deleddian novel in Swedish was a fact, and at that time no one could have dreamed of the successful future that awaited the Sardinian writer.

\section{Concluding remarks}

This analysis has shown that until the year in which she was awarded the Nobel Prize in literature, Deledda did not enjoy any stable and reliable contacts with important mediators in the Swedish book market, and her novels were rarely reviewed. No such individuals that a study focusing on single mediators would have highlighted - a publishing house, a translator or a critic - actually appeared in the Swedish promotion of her works. What this combined field theory/network analysis has shown instead is that Deledda was a common denominator for three intercultural networks. These networks included individuals with different positions (not only in the literary field), and some had strong connections to important institutions. Even though the networks were very different from each other, they all featured two important qualities: first, they were overlapping - i.e. all three networks included several nodes that acted as bridges to the other two networks, which confirms the observation that isolated networks, however distinguished they may be, have limited impact in the literary field. Second, all three networks were intercultural, bringing together Sweden and Italy without relying on intermediaries from more central languages. Taken together, the three networks formed a large and heterogeneous hyper-network, which fully covered the cultural field, including a variety of nodes in terms of sex, age, position and professional field.

This overlapping, intercultural and heterogeneous hyper-network turned out to be crucial for the consecration of Deledda's works and her reputation spreading throughout the world. Moreover, it sheds light on the hitherto unexplored relationships between semiperipheral literary fields, confirming that they do not necessarily communicate through central literatures. Rather, the analysis shows that the semi-peripheries, even those that are not particularly closely related to each other in terms of geography, culture and language structure, such as Italy and Sweden, are directly interconnected by powerful social networks. The multiple mediatorship of transnational literary circulation could hardly be more conspicuous.

\section{Notes}

1. According to Swedish Academy member Kjell Espmark, various surveys show that among the Nobel Laureates in literature awarded in the 1920s, Grazia Deledda is the only one 'who constantly receives a negative judgement' (1986, p. 161, my tr.).

2. Anime oneste ('Honest souls') from 1895 was translated into French in 1899.

3. It should be noted, however, that the prize was assigned in December 1927.

4. On the official website of the Nobel Prize http://www.nobelprize.org/nomination/map2/? person $=2348 \&$ nominee $=$ true $\&$ year $=$ all \&prizes $=$ literatura visualization of the nominations of Grazia Deledda's is provided. Nobel Prize Data Visualization is a useful tool for discovering how nominations are made across countries. In Deledda's case all the nominations came either from Italy or Sweden. As a comparison, the nominations of another candidate for the Nobel Prize who was a contemporary of Deledda, namely the historian and philosopher Guglielmo Ferrero, came from many different parts of the world 
(http://www.nobelprize.org/nomination/map2/?person=2964\&nominee=true\&year=all\&prizes= peace\%2Cliterature. Both websites were accessed on 20 June 2017.

5. Buzelin also noticed that Latour's works 'have so far had no effect on translation studies, including on the work of those specialists who adopt a sociological perspective', and that he 'has shown little interest in interlingual translation' (2007, p. 56).

6. For more details about the debates inside the Swedish Academy that preceded Deledda's prize, see Wahlund (1979), Björkman (1998), Hallengren (2002/2014) and Tiozzo (2009).

7. For this purpose I have consulted a number of different sources: Björkman (1998); Dolfi (1979); Dolfi (1987); Dubravec Labas (2011); Farnetti (2010); Heyer-Caput (2008); King (2005); Wahlund (1979).

8. As we shall see later, Carl Bildt was a Swedish diplomat in Rome and a great admirer of Deledda (Björkman, 1998). Anders Österling's lifelong engagement in Italian literature started very early in his career, and he would later become one of the foremost translators and literary critics of works by Italian authors (Schwartz, 2016; Westerström, 2013). Selma Lagerlöf traveled for long periods in Italy and was in direct contact with Deledda (Dolfi, 1987, p. 71). Henrik Schück visited Italy every year and pled for a Nobel Prize to be awarded to Deledda in 1920 (Espmark, 1986, p. 59). Twice, in 1925 and 1927, he proposed that Deledda be a candidate for the Nobel Prize in literature. Without Schück, argued Enrico Tiozzo, Deledda would not have been awarded the prize (Tiozzo, 2013, p. 99). The archeologist Oscar Montelius spent much time in Rome (Gustavsson, 2015), as did Erik Axel Karlfeldt, who knew Italian well and was inspired by many Italian authors (Björkman, 1998, pp. 136-164). The Swedish author Verner von Heidenstam also spent many years in Rome during his lifetime (http://www.svenskaakademien.se/svenska-akademien/ ledamotsregister).

9. The information on this network originated from articles published in the daily newspaper Dagens Nyheter on the following dates: 10 February 1910; 24 March 1910; 23 November 1910; and 29 November 1910.

10. For instance, Ellen Lundberg-Nyblom autobiographical works Bland italienare: intryck och upplevelser (1907), Från Fyrisån till Capris klippor (1931), and Från Norrström till Arno: nya minnen (1932); Carina Burman's biography Vi romantiska resenärer: med Ellen Rydelius $i$ Rom (2016); and Margherita Giordano Lokrantz's study on Selma Lagerlöf from an Italian perspective (1990). Useful information on less consecrated female translators can also be obtained from Svenskt översättarlexikon - an online encyclopedia of Swedish translators (http://www.oversattarlexikon.se/).

11. The Swedish Academy has 18 members, each of whom is elected for a lifetime commitment. When a member passes away, a new member is elected. In the years 1913-1926, the Swedish Academy consisted of the following persons: Gottfrid Billing, Albert Gellerstedt, Claes Annerstedt, Carl Bildt, Gustaf Retzius, Harald Hjärne (president of the Nobel Committee 1912-1922), Erik Axel Karlfeldt, Ivar Afzelius, Vitalis Norström, Per Hallström (president of the Nobel Committee 1922-1944), Verner von Heidenstam, Henrik Schück, Sven Hedin, Selma Lagerlöf (1914), Oscar Montelius (1917), Hjalmar Hammarskjöld (1918), Adolf Noreen (1919), Anders Österling (1919), Nathan Söderblom (1921), Fredrik Böök (1922), Albert Engström (1922), Tor Hedberg (1922), Axel Kock (1924), Hans Larsson (1925) and Bo Bergman (1925). The single year between parenthesis marks members elected after 1913.

12. 'permetterait de repérer la multipositionnalité et le rôle d'intermédiaire parfois occulte de certains individus' (Sapiro, 2006, p. 56).

13. Another Italophile in the Academy at the time was the author Verner von Heidenstam (elected in 1912), who had lived in Rome for nine years at the end of the twentieth century. There is, however, no evidence that he had argued for or against Deledda.

14. 'medlemmar ur den italienska kolonien i härstädes och svenskar som på ett eller annat sätt ha förbindelser till Italien eller italienare'

15. Salomon Eberhard, Karl Warburg, Holger Nyblom, Oscar Björck, Gösta Mittag-Leffler, Osvald Sirén, Anton Lindsström. 
16. Such as Commander Seth von Konow, who was also the secretary of the Swedish Tourist Association in the years 1909-1914; Baron Lage Staël von Holstein; Count Vinci and Count Francesco Bottaro-Costa (former Italian Ambassador in Sweden).

17. The articles were published in the year 1910, when the Society was newly founded: 10 February; 24 March; 23 November; 29 November.

18. It should also be mentioned that Mittags-Leffler was the brother of a famous Swedish writer, Anne Charlotte Leffler, who, after having married an Italian, passed away in 1892 at the age of 42 , shortly after giving birth to her first child.

19. In 1920, the mathematician Vito Volterra became vice president of one of Italy's most ancient scientific academies, Accademia dei Lincei.

20. Furthermore, it should be noted that a Swedish-Italian society had been constituted in 1925 in Gothenburg (Dagens Nyheter 15 March 1925), counting among its nodes Ebba Atterbom, who had introduced Deledda in Sweden by translating the novel Elias Portolu in 1903. This association lasted at least until 1945, which was the year of the last issue of its journal, SverigeItalien (Sweden-Italy).

21. Some of the network's nodes were: Ellen Key, Selma Lagerlöf, Sophie Elkan, Hilda Sachs, Gunhild Bergh, Ebba Atterbom, Amelie Posse, Ellen Lundberg-Nyblom, Astrid Ahnfeldt and Ellen Rydelius.

22. Hilda Sachs was a foreign correspondent in Rome in the years 1908-1910, and Gunhild Bergh had the same function from the early 1920s until her death in 1961.

23. The letter from Nanna Bendixsen to Wilhelm Widstrand is dated 20 May 1903 and is preserved in the publishing company's archive in Stockholm (Arkiv Wahlström \& Widstrand, Korrespondens, 1902-1903, E 1:2.).

24. 'Senast idag kom ett kort från henne med underrättelse att "Elias Portolu" i Revue des Deux Mondes haft stor framgång i Frankrike och att förläggaren Calman-Levy nu ämnar ge ut den i bokform.'

\section{Disclosure statement}

No potential conflict of interest was reported by the author.

\section{Notes on contributor}

Cecilia Schwartz is associate professor of Italian at Stockholm University. Her research is focused on transnational Italian literature and she is currently participating in the research program Cosmopolitan and vernacular dynamics in world literatures with the project 'Made in Italy. A diachronic study of literary circulation and translation in the semi-periphery', which focuses on the translation flow from Italy to Sweden and seeks to provide a better understanding of the semi-peripheral dynamics in world literature. Schwartz is also a translator and she occasionally contributes to various Swedish newspapers.

\section{ORCID}

Cecilia Schwartz (D) http://orcid.org/0000-0002-5751-8834

\section{References}

Bildt, C. N. D. Svenskt biografiskt lexikon [Swedish Biographical Encyclopedia] (art by G. Jacobson). Retrieved February 8, 2018, from https://sok.riksarkivet.se/sbl/artikel/18207

Björkman, S. (1998). Dante, D’Annunzio, Deledda - Erik Axel Karlfeldt och den italienska diktkonsten [Dante, D'Annunzio, Deledda - Erik Axel Karlfeldt and the Italian poetry]. In H. Landberg 
(Ed.), Mellan myrten och rönn. Tolv texter om Erik Axel Karlfeldt (pp. 136-164). Stockholm: Wahlström \& Widstrand.

Buzelin, H. (2007). Translation studies, ethnography and the production of knowledge. In P. StPierre \& C. K. Prafulla (Eds.), Translation - reflections, refractions, transformations (pp. 3956). Amsterdam/Philadelphia: John Benjamins Publishing Company.

Camboni, M. (2004). Networking women: Subjects, places, links Europe-America: Towards a rewriting of cultural history, 1890-1939. Proceedings of the international conference, Macerata, March 25-27, 2002. Rome: Edizioni di storia e letteratura.

Casanova, P. (2004). The world republic of letters. Cambridge, Massachusetts: Harvard University Press.

Casanova, P. (2010). Consecration and accumulation of literary capital: Translation as unequal exchange. In M. Baker (Ed.), Critical readings in translation studies (pp. 287-303). London \& New York: Routledge.

Dolfi, A. (1979). Grazia Deledda. Milano: Mursia.

Dolfi, A. (Ed.). (1987). Grazia Deledda. Biografia e romanzo. Catalogo della mostra [Grazia Deledda. Biography and novel. Catalog of the exhibition]. Rome: Treccani.

Dubravec Labas, D. (2011). Grazia Deledda e la "piccola avanguardia romana" [Grazia Deledda and the "little Roman vanguard"]. Roma: Carocci.

Espmark, K. (1986). Det litterära Nobelpriset. Principer och värderingar bakom besluten [The literary Nobel prize. Principles and valuations behind the decisions]. Stockholm: Norstedts.

Farnetti, M. (Ed.). (2010). Chi ha paura di Grazia Deledda? Traduzione - Ricezione - Comparazione [Who is afraid of Grazia Deledda? Translation - Reception - Comparison]. Rome: Iacobelli.

Furuland, G. Ebba Atterbom (1868-1961). In Svenskt översättarlexikon [Swedish encyclopedia of translators] http://www.oversattarlexikon.se/artiklar/Ebba_Atterbom

Gustavsson, A. (2015). Svenska arkeologer och järnåldersforskning i Italien under slutet av 1800talet [Swedish archaeologists and iron age research in Italy in the late 1800s]. Romhorisont, $63,12-13$.

Hallengren, A. (2002/2014). Grazia Deledda: Voice of Sardinia. Retrieved from https://www. nobelprize.org/nobel_prizes/literature/laureates/1926/deledda-article.html

Heilbron, J. (1999). Towards a sociology of translation. Book translations as a cultural worldsystem. European Journal of Social Theory, 2/4, 429-444.

Heyer-Caput, M. (2008). Grazia Deledda's dance of modernity. Toronto, Buffalo, London: University of Toronto Press.

Jansen, H., \& Wegener, A. (Eds.). (2013). Authorial and editorial voices in translation. 1. Collaborative relationships between authors, translators, and performers. Quebec: Éditions québecoises de l'oeuvre.

King, M. (2005). Grazia Deledda. A legendary life. Leicester: Troubador.

Marin, A., \& Wellman, B. (2014). Social network analysis: An introduction. In J. Scott, \& P. J. Carrington (Eds.), The SAGE handbook of social network analysis (pp. 2-23). London: SAGE Publications. doi:10.4135/9781446294413.n2

Meylaerts, R., Gonne, M., Lobbes, T., \& Sanz Roig, D. (2017). Cultural mediators in cultural history. What do we learn from studying mediators' complex transfer activities in interwar Belgium? In E. Brems, O. Réthelyi, \& T. van Kalmthout (Eds.), Doing double Dutch. The international circulation of literature from the low countries (pp. 67-91). Leuven: Leuven University Press.

Moretti, F. (2003). More conjectures. New Left Review, 20, 73-81.

Pięta, H. (2016). On translation between (semi-)peripheral languages: An overview of the external history of Polish literature translated into European Portuguese. The Translator, 22(3), 354-377.

Pym, A. (2007). Cross-cultural networking: Translators in the French-German network of petites revues at the end of the nineteenth century. Meta: journal des traducteurs / Meta: Translators' Journal, 52, 744-762.

Sapiro, G. (2006). Réseaux, institution(s), et champ [Networks, institution(s) and field]. In D. de Marneffe, \& B. Denis (Eds.), Les Réseaux littéraires (pp. 44-59). Bruxelles: Le Cri.

Schwartz, C. (2016). Introducing Italy, 1948-1968: The importance of symbolic capital and position of literary mediators in the semi-periphery. Moderna Språk, 2, 75-107. 
Schwartz, C. (2017). Semi-peripheral dynamics. Inclusion modalities of Italian literature in Sweden. Journal of World Literature, 2, 488-511.

Svensén, B. (2001). Nobelpriset i litteratur. Nomineringar och utlåtanden 1901-1950. Del II 19211950. [The Nobel Prize in literature. Nominations and judgements 1901-1950. Part II 19211950]. Stockholm: Svenska Akademien/ Norstedts.

Tahir-Gürçağlar, S. (2007). Chaos before order: Network maps and research design in DTS. Meta: Journal des Traducteurs, 52, 724-743.

Tiozzo, E. (2009). La letteratura italiana e il premio Nobel. Storia, critica e documenti [Italian literature and the Nobel prize. History, criticism and documents]. Florence: Leo S. Olschki.

Tiozzo, E. (2013). Il Nobel svelato, Segreti, errori e verdetti del premio per la letteratura. [The Nobel unveiled. Secrets, errors and verdicts of the literary prize]. Torino: Nino Aragno Editore.

van Es, N., \& Heilbron, J. (2015). Fiction from the periphery: How Dutch writers enter the field of English-language literature. Cultural Sociology, 9(3), 296-319.

Wahlund, P. E. (1979). Frändskaper. Aderton essayer [Kinships. Eighteen essays]. Stockholm: Bonniers.

Westerström, J. (2013). Den ständige Anders Österling. En litteraturmänniskas alla sidor 1919-1981 [The permanent Anders Österling. A literary person's all sides 1919-1981]. Stockholm: Atlantis. 